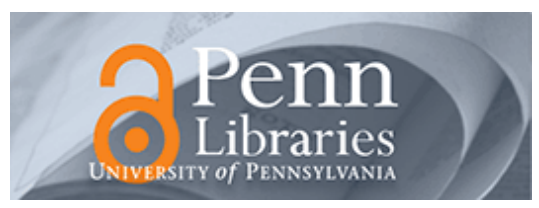

Manuscript Studies

Volume 3

Issue 2 Fall 2018

Article 2

2019

\title{
Translating Machiavelli's Prince in Early Modern England: New Manuscript Evidence
}

Alessandra Petrina

Università degli Studi di Padova, Italy, alessandra.petrina@gmail.com

Follow this and additional works at: https://repository.upenn.edu/mss_sims

Part of the Italian Language and Literature Commons, and the Medieval Studies Commons

\section{Recommended Citation}

Petrina, Alessandra (2019) "Translating Machiavelli's Prince in Early Modern England: New Manuscript Evidence," Manuscript Studies: Vol. 3 : Iss. 2 , Article 2.

Available at: https://repository.upenn.edu/mss_sims/vol3/iss $2 / 2$

This paper is posted at ScholarlyCommons. https://repository.upenn.edu/mss_sims/vol3/iss $2 / 2$

For more information, please contact repository@pobox.upenn.edu. 


\title{
Translating Machiavelli's Prince in Early Modern England: New Manuscript Evidence
}

\author{
Abstract \\ 'All Estates and signiories wich haue had and doe beare rule ouer men, haue either byn and are Comon \\ weales or Monarchies': thus begins Sion MS L40.2/E24, preserved in Lambeth Palace Library, London. \\ Written in clear anglicana, it offers a translation of Machiavelli's Prince. It is a welcome addition to the \\ already known English manuscript translations preceding Dacres's printed version. The codex shows how \\ the scribe paid attention to historical allusions in the text. It offers a faithful and elegant translation; the \\ layout may offer interesting suggestions as to the modalities of reading in early modern England. This \\ article presents hypotheses on the manuscript's provenance, compares this translation with four \\ contemporary versions, and discusses its possible use.
}

\section{Keywords}

Machiavelli, Principe, Translation, England, Lambeth Palace Library, Manuscript studies, Prince, Early Modern 


\section{MANUSCRIPT STUDIES}

A Journal of the Schoenberg Institute for Manuscript Studies

VOLUME 3, NUMBER 2

(Fall 2018)

Manuscript Studies (ISSN 2381-5329) is published semiannually

by the University of Pennsylvania Press

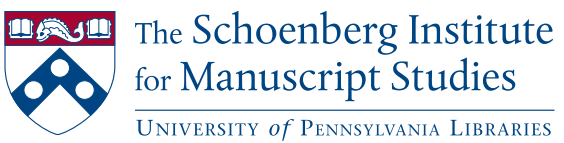




\title{
MANUSCRIPT STUDIES
}

\author{
VOLUME 3, N UMBER 2 \\ (Fall 2018)
}

\section{ISSN 2381-5329}

Copyright ( 2018 University of Pennsylvania Libraries and University of Pennsylvania Press. All rights reserved.

Published by the University of Pennsylvania Press, 3905 Spruce Street, Philadelphia, PA 19104.

Printed in the U.S.A. on acid-free paper.

Manuscript Studies brings together scholarship from around the world and across disciplines related to the study of premodern manuscript books and documents, with a special emphasis on the role of digital technologies in advancing manuscript research. Articles for submission should be prepared according to the Chicago Manual of Style, $16^{\text {th }}$ edition, and follow the style guidelines found at http://mss.pennpress.org.

None of the contents of this journal may be reproduced without prior written consent of the University of Pennsylvania Press. Authorization to photocopy is granted by the University of Pennsylvania Press for libraries or other users registered with Copyright Clearance Center (CCC) Transaction Reporting Service, provided that all required fees are verified with CCC and paid directly to CCC, 222 Rosewood Drive, Danvers, MA 01923. This consent does not extend to other kinds of copying for general distribution, for advertising or promotional purposes, for creating new collective works, for database retrieval, or for resale.

\section{SUBSCRIPTION INFORMATION:}

Single issues: $\$ 30$

Print and online subscriptions: Individuals: \$40; Institutions: \$92; Full-time Students: \$30 International subscribers, please add $\$ 18$ per year for shipping.

Online-only subscriptions: Individuals: $\$ 32$; Institutions: $\$ 80$

Please direct all subscription orders, inquiries, requests for single issues, address changes, and other business communications to Penn Press Journals, 3905 Spruce Street, Philadelphia, PA 19104. Phone: 215-573-1295. Fax: 215-746-3636. Email: journals@pobox.upenn.edu. Prepayment is required. Orders may be charged to MasterCard, Visa, and American Express credit cards. Checks and money orders should be made payable to "University of Pennsylvania Press" and sent to the address printed directly above.

One-year subscriptions are valid January 1 through December 31. Subscriptions received after October 31 in any year become effective the following January 1 . Subscribers joining midyear receive immediately copies of all issues of Manuscript Studies already in print for that year.

Postmaster: send address changes to Penn Press Journals, 3905 Spruce Street, Philadelphia, PA 19104.

Visit Manuscript Studies on the web at mss.pennpress.org. 


\section{MANUSCRIPT STUDIES}

A Journal of the Schoenberg Institute for Manuscript Studies

VOLUME 3 , NUMBER 2

\section{Articles}

Notes of Exchange: Scribal Practices and Vernacular

Religious Scholarship in Early Modern North India

Tyler Williams

Translating Machiavelli's Prince in Early Modern England:

New Manuscript Evidence

Alessandra Petrina

Provenance in the Aggregate: The Social Life of an Arabic

Manuscript Collection in Naples

Paul Love

Illuminated Leaves from an Ethiopic Gospel Book in the

Newark Museum and in the Walters Art Museum

JACOPO GNISCI

Re-Conceptualizing the Poems of the Pearl-Gawain

Manuscript in Line and Color

Maidie Hilmo

\section{Annotations}

A Codicological Assessment of Three Gospel Books with

Sideways-Oriented Illustrations Displayed in the

Metropolitan Museum of Art's Armenia Exhibition

ZsUZsANnA GULÁcsI

A Psalter from Maillezais at Maynooth

Peter J. Lucas and Angela M. Lucas 
iv | Journal for Manuscript Studies

A Dossier of Texts for the Augustinian Hermits of Lucca

Thomas M. IzBicki

Digitizing the University of Pennsylvania's Indic Manuscripts

Benjamin J. Fleming

Reviews

Kathryn M. Rudy. Piety in Pieces: How Medieval Readers

Customized Their Manuscripts

A. R. BennetT

Georgi R. Parpulov. Toward a History of Byzantine Psalters, ca. 850-1350 AD

Barbara Crostini

Corine Schleif and Volker Schier, eds. Manuscripts

Changing Hands

JoHAN OOSTERMAN

495

Nichols, Stephen G. From Parchment to Cyberspace:

Medieval Literature in the Digital Age

BRIDGET WHEARTY

499

List of Manuscripts Cited

505 


\title{
Translating Machiavelli's Prince in Early Modern England New Manuscript Evidence
}

\author{
Alessandra Petrina \\ Università degli Studi di Padova
}

D

IABOLUS LOQUITUR: THE DEVIL speaks. This is what an anonymous early modern reader has written in the margin of chapter XVIII of The Prince by Niccolo Machiavelli (1469-1527), as the writer expounds his controversial theory of the lion and the fox: the prince, Machiavelli contends, should imitate the lion in its ferociousness and the fox in its cunning. "This advice would not be sound if all men were upright," Machiavelli adds; as they are not, the prince had better be prudent. Hence the reader's censoriousness.

The marginalium appears on folio 37 of British Library, MS Harley 967, a codex containing an early English translation of The Prince. The reader's condemnation may not surprise us; and yet, although a number of manuscript translations have survived, and although we have copies of The Prince in Italian, French, and Latin, owned and annotated by English readers, such instances of strongly expressed disapprobation are very rare. It is now a critical commonplace to assume that the European reception of Machiavelli,

1 The modern translation used (unless otherwise noted) is Niccolò Machiavelli, Machiavelli: The Prince, ed. and trans. Quentin Skinner and Russell Price (Cambridge: Cambridge University Press, 1988), here 62. 
and especially of The Prince, followed a dual path: on the one hand, the book was condemned and its author vituperated for their subversive, even blasphemous statements; on the other, the treatise was hailed as a useful discussion on the behavior of rulers, a description of a political skill that could benefit its opponents as well as its practitioners. ${ }^{2}$ Elizabethan and Jacobean playwrights might interweave in their works political meditations reflecting Machiavelli's own arguments, ${ }^{3}$ just as they upheld the more popular and facile vituperation of the Florentine writer as an agent of the devil; this nuanced attitude might reflect their double role as readers of the page and writers for the stage. Readers of The Prince in early modern England did not join the vociferous group of detractors on page and stage $;{ }^{4}$ to judge from the little they wrote in the margins, they preferred to deal quietly with historical and topical allusions, or to explain foreign or arcane words, or simply to underline or mark interesting passages. ${ }^{5}$ The Prince, therefore, in its manuscripts and early printed copies, represents a good case study for the investigation of reading habits in early modern England, since the echo generated in contemporary plays and pamphlets differs greatly from the spontaneous

2 Victoria Kahn, "Machiavelli's Afterlife and Reputation to the Eighteenth Century," in The Cambridge Companion to Macbiavelli, ed. John M. Najemy (Cambridge: Cambridge University Press, 2010), 239-55.

3 András Kiséry, Hamlet's Moment: Drama and Political Knowledge in Early Modern England (Oxford: Oxford University Press, 2016), 37-88.

4 These were especially vocal, as shown by the prologue of Christopher Marlowe's The Jew of Malta, and by the numerous allusions in Shakespeare, Jonson, and others. See Nigel W. Bawcutt, "Machiavelli and the Elizabethans: A New Examination," Études Anglaises 30 (1977): 455-62; Jacqueline E. M. Latham, "Machiavelli, Policy, and The Devil's Charter," Medieval and Renaissance Drama in England 1 (1984): 97-108; Enrico Stanic, "Machiavellianism in Christopher Marlowe's The Jew of Malta," in Machiavellian Encounters in Tudor and Stuart England. Literary and Political Influences from the Reformation to the Restoration, ed. Alessandro Arienzo and Alessandra Petrina (Farnham: Ashgate, 2013), 75-88.

5 The study of marginalia in early modern books has recently gained new impetus thanks to Lisa Jardine and Anthony Grafton, “Studied for Action': How Gabriel Harvey Read His Livy,” Past \& Present 129 (1990): 30-78, William H. Sherman, Used Books: Marking Readers in Renaissance England (Philadelphia: University of Pennsylvania Press, 2008), and Kevin Sharpe, Reading Revolutions: The Politics of Reading in Early Modern England (New Haven: Yale University Press, 2000), among others. The present article benefits greatly from their contribution. 
reactions of readers. It is also an exemplary instance of an early modern text for which manuscript dissemination and printed circulation coexisted for at least a century after its composition. ${ }^{6}$ This is due to the contentious, controversial, potentially incendiary contents; the quality of the writing, a wonderful blend of political speculation and local history; the style, gnomic and exemplary, as crystal clear in its surface meaning as the political or ideological concern is obscure and ambiguous. These characteristics, combined with the unique background against which the book was composed, helped to provide this text with a highly individual circulation in early modern Europe, offering an interesting example of what Harold Love would call scribal publication. ${ }^{7}$

In England this phenomenon is observable with special clarity, as a conspectus of key dates shows. Completed in 1513, first published in Rome in 1532, the text did not appear in a printed English translation until 1640; but it was known well beyond the colorful but misleading allusions we find in much contemporary writing. ${ }^{8}$ Before its publication, one manuscript of the text had already arrived in England, ${ }^{9}$ and copies of the earliest Italian editions are still preserved in libraries in the British Isles, sometimes with annotations in English hands. The first French and Latin translations

6 On the early reception of Machiavelli, see Sydney Anglo, Macbiavelli: The First Century. Studies in Enthusiasm, Hostility, and Irrelevance (Oxford: Oxford University Press, 2005). On the immediate reception of The Prince in Italy, see Brian Richardson, "The Prince and Its Early Italian Readers," in Niccolò Machiavelli's “The Prince”: New Interdisciplinary Essays, ed. Martin Coyle, 18-39 (Manchester: Manchester University Press, 1995).

7 See Harold Love, The Culture and Commerce of Texts: Scribal Publication in SeventeenthCentury England (Amherst: University of Massachusetts Press, 1998). Analyzing some of John Donne's manuscripts, Wollman also shows how manuscript culture allows a dialogue between texts and readers, a situation that is repeated in this instance. Richard B. Wollman, "The 'Press and the Fire': Print and Manuscript Culture in Donne's Circle," Studies in English Literature 33 (1993): 85-97.

8 Alessandra Petrina, Machiavelli in the British Isles: Two Early Modern Translations of The Prince (Farnham: Ashgate, 2009), 1-45. See also Alessandro Arienzo and Alessandra Petrina, eds., Machiavellian Encounters in Tudor and Stuart England: Literary and Political Influences from the Reformation to the Restoration (Farnham: Ashgate, 2013).

9 John Humphreys Whitfield, ed., Niccolò Machiavelli: Il Principe, with an Essay on The Prince (Paris: Mouton, 1969). 
appeared soon, ${ }^{10}$ and toward the end of the sixteenth century the knowledge of Machiavelli in England was boosted by the London printer John Wolfe (1548?-1601), who between 1584 and 1588 printed Discorsi, Principe, L'Arte della Guerra, Historie Fiorentine and L'asino d'oro. ${ }^{11}$ L'arte della Guerra, perhaps the best known of Machiavelli's works in the sixteenth century, had already been translated by Peter Whitehorne and printed in London by John Kingston in 1560, with a dedication to Queen Elizabeth. An English version of The Florentine Historie appeared in 1595. The English printing presses in the sixteenth century were often busy with Machiavelli's works.

At the same time, scribal publication, in the British Isles as in the rest of Europe, still played a very important role in the circulation of The Prince. It took different forms: maxims were gathered with sententiae by other historical and political writers, such as Francesco Guicciardini; ${ }^{12}$ passages appeared in commonplace books; ${ }^{13}$ Machiavelli's text was summarized and reduced to a collection of aphorisms, as we can see in "Tractatus Politicus, de Gubernatione Reipublicae" (now British Library, MS Harley 966, fols. $1 \mathrm{r}-12 \mathrm{r}$ ); and above all, manuscript translations of the text were made, copied, and quoted from. Four different translations appearing in different manuscripts have hitherto been identified prior to the first printed translation (1640, by Edward Dacres):

10 The first printed French translations (by Gaspard d'Auvergne and Guillaume Cappel) appeared in 1553, while the Latin version by Sylvester Telius was printed in 1560 .

11 Fabio Massimo Bertolo, "John Wolfe: un editore inglese tra Aretino e Machiavelli," in Il Rinascimento italiano di fronte alla Riforma: letteratura e arte. Sixteenth-Century Italian Art and Literature and the Reformation, ed. Chrysa Damianaki, Paolo Procaccioli, and Angelo Romano (Rome: Vecchiarelli, 2005), 201; Ian Gadd, "Wolfe, John," in Oxford Dictionary of National Biography (Oxford: Oxford University Press, 2004), doi: 10.1093/ref:odnb/29834; Denis B. Woodfield, Surreptitious Printing in England, 1550-1640 (New York: Bibliographical Society of America, 1973).

12 Valentina Lepri, "Machiavelli in The Quintesence of Wit and His English Military Readers," in Macbiavellian Encounters in Tudor and Stuart England: Literary and Political Influences from the Reformation to the Restoration, ed. Alessandro Arienzo and Alessandra Petrina (Farnham: Ashgate, 2013), 45-57.

13 A famous instance is Sir William Drake's notebook, now London Library, MS Ogden 7. See Petrina, Macbiavelli in the British Isles, 63-67. 
Translation A:

1. London, British Library, MS Harley 6795.vi, fols. 103r-159v

2. Cambridge (MA), Harvard University, Houghton Library, MS Eng. 1014

3. London, British Library, MS Harley 967

4. Oxford, Bodleian Library, MS Ashmole 792.iii, fols. 1r-40r

Translation B:

1. London, British Library, MS Harley 364.xx, fols. 46r-109v

2. London, British Library, MS Harley 2292

Translation C:

1. Oxford, Queen's College Library, MS 251

Translation D:

1. Edinburgh, National Library of Scotland, MS Hawthornden 2064, fols. $144 \mathrm{r}-187 \mathrm{v}^{14}$

Only for translation D do we have the name of the translator: William Fowler (1560/61-1615), a Scottish poet and courtier. In his case we do not possess a presentation copy, but only a very rough draft. The other translations remain obstinately anonymous and provide very few clues as to the circumstances in which they were composed. However, it is happily the fate of such studies that one may never say that they have reached a point of completion. In 2014 I received a communication from Richard J. Palmer, librarian and archivist at Lambeth Palace Library, who was contacting me in connection with a manuscript recently acquired by Lambeth Palace, as part of the collection formerly belonging to Sion College Library and transferred to Lambeth in 1996. In these rather unexpected surroundings, another early modern English translation of Machiavelli's Prince had surfaced. The present article provides a presentation and a preliminary assessment of this discovery.

14 Petrina, Macbiavelli in the British Isles, 51. 
Manuscript Sion L40.2/E24 is a small paper octavo in its original binding. The binding $(154 \times 105 \mathrm{~mm})$ is dark leather with an embossed Tudor rose on the front and back (a detail that contrasts with the possible later dating of the codex, and that might be explained with the fact that the cover was taken from a different manuscript) and slight gold embossing on the spine; the manuscript is paginated rather than foliated. It contains one guardsheet, followed by four other sheets (numbered $\mathrm{i}-\mathrm{x}$ ); on page $\mathrm{x}$ there is the Sion College Library stamp; pages 1-260 contain the Machiavelli translation. The page facing the opening page of the translation is blank (now carrying the Sion College Library stamp); it is whole and ruled, but it has no writing on it. The same happens in the case of the last page (p. 260): the facing page was originally blank, though not ruled, and pasted to the cover; it is now rather damaged. There is no discernible watermark on the pages, which are browned but otherwise show signs of little use. Some marginalia have disappeared or have been reduced, due to some slight trimming, but the actual text seems whole; the lack of the dedicatory epistle to the Medici is probably due to a deliberate decision on the part of the translator/ scribe. The translation does not show any great sign of wear, and the marginalia appear to have been inserted by the same hand. On pages $\mathrm{i}-\mathrm{x}$ we find a sermon, in an early seventeenth-century hand, on the Epistle of James 1:2 ("My brethren, count it all joy when ye fall into divers temptations"). ${ }^{15}$ The hand penning the Machiavelli translation appears to be slightly earlier than the one responsible for the sermon: it may be dated to the very late sixteenth century, or more probably early seventeenth, though there is no certainty on this point. ${ }^{16}$ Adjacency offers no further information: Arc.L.40.2/E.23 contains a section of Chaucer's Canterbury Tales (fifteenth century), while Arc.L.40.2/E.25 has an English version of The Prick of Conscience (fourteenth to fifteenth centuries). ${ }^{17}$

15 I would like to thank Richard J. Palmer for identifying the topic of the sermon.

16 I wish to thank Allison L. Steenson for helping me with the paleographic characteristics of the manuscript.

17 Both manuscripts are described in N. Ker, Medieval Manuscripts in British Libraries, vol. 1: London (Oxford: Clarendon Press, 1969), 288-89. Ker of course does not describe the manuscript under examination here. 
A note on the front pastedown reads: "Given to Sion College Library by Mr Bagford of the Charter House Augt 12. 1714” (fig. 1). This is confirmed in the 1724 Catalogue of Sion College Library, compiled by the Reverend William Reading, its librarian. The manuscript is mentioned in the section dedicated to "Libri Manuscripti \& nonnulli rariores impressi, sub arctiori custodia in Archivis adservati," under Forulus E.: "Nicolas Machiavel's Principles. 8vo. John Bagford." Although the library possessed other volumes by Machiavelli, they seem unrelated to this manuscript-and indeed it is somewhat difficult to associate this library with the Florentine writer. A seventeenth-century foundation, created by Dr. Thomas White (d. 1624), ${ }^{18}$ Sion College itself was granted a Charter of Incorporation by Charles I in 1630. ${ }^{19}$ After White's death, his kinsman and executor, John Simpson, rector of St. Olave Hart, sustained the cost for the erection of the library; books were, at least initially, provided almost exclusively thanks to donations, although between 1710 and 1836 it benefited from the Copyright Act passed during the reign of Queen Anne, according to which the library was "entitled to a copy of every work entered at Stationers' Hall." ${ }^{20}$ The nature of the Sion collection, dedicated mainly to religious manuscripts, has helped the obscurity in which the Machiavelli manuscript has lived. Indeed, John Bagford himself appears in the list of donors for religious books rather than political treatises, ${ }^{21}$ as shown by the Benefactors' Register: "1712-13-14. Mr John Bagford, Pensioner at the Charterhouse gave an English Concordance to the Holy Bible. Fol. London 1550. Common prayer in Welch. Fol. London 1664."22

18 A history of Sion College Library can be found in E. H. Pearce, Sion College and Library (Cambridge: Cambridge University Press, 1913).

19 W. H. Milman, A Brief Account of the Library of Sion College, in the City of London, its Foundation, its Growth, and its Present State (London: Sion College, 1897), 1.

20 Milman, A Brief Account of the Library of Sion College, 3.

21 William Reading, Bibliothecae cleri Londinensis in Collegio Sionensi Catalogus (London: Watts, 1724), 39.

22 London, Lambeth Library, MS Sion L40.2/E64, p. 224. See also Pearce, Sion College and Library, 273. 


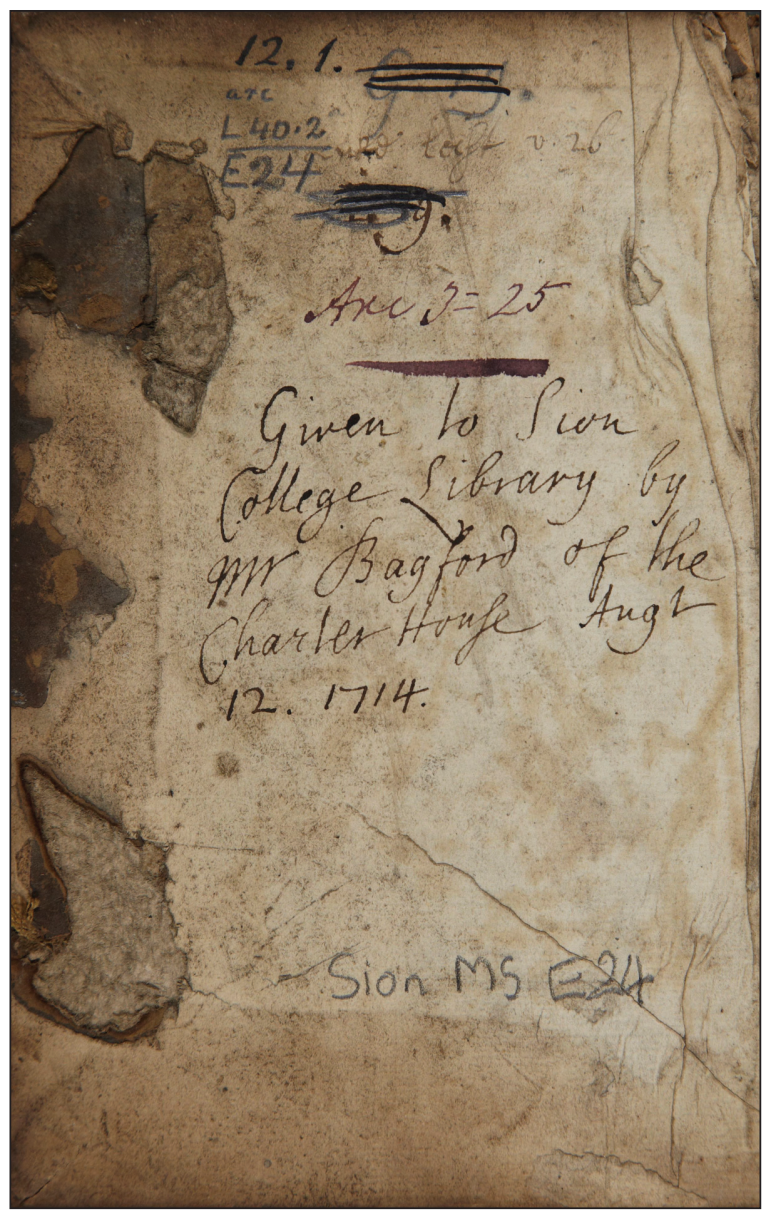

FIGURE 1. London, Lambeth Palace Library, MS Sion L40.2/E24, front pastedown. Reproduced with permission of Lambeth Palace Library.

It is unclear why Bagford (1650/51-1716), who had apparently remarried in 1703, should spend his last years as a pensioner at the Charterhouse. He is a colorful personality; a quick look at his life and activities may help us to get a better appreciation of his donation to Sion College Library. Born in 1650 in London, he was a shoemaker (he even wrote a little tract about this 
trade), ${ }^{23}$ without academic education, but dominated by a passion for books. He became a bookseller and an antiquary, helped to build some of the great libraries of his time (such as those of Bishop John Moore of Ely, Samuel Pepys, Robert Harley, and Sir Hans Sloane), and was a friend of antiquaries and scholars such as Thomas Hearne. He was fascinated by the physical, sensorial qualities of books: typeface, layout, and colophons of printed books; rubrication and illumination in manuscripts. He was also deeply interested in the work of early printers, such as William Caxton or Wynkyn de Worde, and attempted a systematic study of early printing in London. The assessments of his work vary considerably. John Nichols, in his Literary Anecdotes of the Eighteenth Century (1812), provides temperate praise: "Destitute as he appears to have been of the benefit of a liberal education, by his great ingenuity and industry he seems to have acquired a degree of accurate knowledge that, all things considered, is really wonderful." ${ }^{24}$ On the other hand, William Blades made Bagford into one of the villains in his Enemies of Books (1880), calling him “a wicked old biblioclast," who "went about the country, from library to library, tearing away title-pages from rare books of all sizes. ${ }^{25}$ Chas. T. Jacobi described him as "an antiquarian collector, who had a mania for mutilating all the books he could lay hands on, in order to collect title-pages, old types, printers' colophons, etc." ${ }^{26}$ An examination of his legacy makes this mixed response even harder to assess: a number of intellectuals benefited from his undoubted flair for discovering forgotten manuscripts and printed books, and acknowledged his help; ${ }^{27}$ at the same

23 Theodor Harmsen, "Bagford, John," in Oxford Dictionary of National Biography (Oxford: Oxford University Press, 2004), doi:10.1093/ref:odnb/1030. See also William Younger Fletcher, "John Bagford and His Collections," Transactions of the Bibliographical Society 4 (1896-98): 185-201; Milton McC. Gatch, "John Bagford as a Collector and Disseminator of Manuscript Fragments," Library 7 (1985): 95-114; Milton McC. Gatch, “John Bagford, Bookseller and Antiquary," British Library Journal 12, no. 2 (1986): 150-71.

24 John Nichols, Literary Anecdotes of the Eighteenth Century (London: Printed for the Author, 1812), vol. 6, part 2, 464.

25 William Blades, The Enemies of Books (London: Trübner, 1880), 96.

26 Chas. T. Jacobi, Gesta Typographica or a Medley for Printers and Others (London: Elkin Mathews, 1897), 29-30.

27 Gatch, "John Bagford as a Collector and Disseminator"; Gatch, "John Bagford, Bookseller and Antiquary." 
time, what is extant of the volumes he put together during his lifetime, now in the Harley and Sloane collections in the British Library, gives us a few surprises.

These volumes were bought by Edward Harley after Bagford's death and subsequently incorporated in the British Museum; they consist of collections of leaves from printed books and manuscripts, interspersed with Bagford's own notes. His notes show a voracious curiosity and a good business sense, but also a lack of academic training that inevitably made his friends doubt his ability to write bibliographical works, as was his desire. His command of the English language was doubtful, as shown by the manuscript title of his great project: "The Hihstory of Tipography, its Originall and prograse from athentick recordes, maniscriptes, and printed bookes, collected with grate paynes, by Jo. Bagford." ${ }^{28}$ On the other hand, his collections of fragments include precious leaves from illuminated manuscripts and cuttings from parchment and paper codices; but a case may be made for his being not a biblioclast but a preserver of books and manuscript fragments, although in some instances he did cut up early printed books and manuscripts. Had they been preserved in their original state, the British Museum folio volumes might have given us a precious insight into the intellectual attitudes of early eighteenth-century English antiquarianism. Unfortunately, in 1890, as part of a policy of transfers between different departments of the museum, Bagford's collection was dismembered. ${ }^{29}$ All the leaves and colophons of printed books in Bagford's collection were lifted out of the original volumes; they are now untraceable, although presumably in the British Library, while the folio volumes in the Manuscript section still preserve Bagford's notes and the manuscript fragments he gathered.

The collection in the present mutilated state consists of eighty-six folio volumes; ${ }^{30}$ there is, besides, at least one other volume in the Rare Books

28 Quoted in Jacobi, Gesta Typographica, 30. The spelling is original.

29 P. R. Harris, A History of the British Museum Library, 1753-1973 (London: British Library, 1998), 351.

30 London, British Library, MSS Harley 5903, 5906b, 5908-10, 5914-5954, 5956-78, 598698 (5934, 38, 41, 49, 59, 66, 78 are bound in one volume); and MSS Sloane 885, 1044, 1086, 1983. A "rough list of the contents," compiled by A. W. Pollard, is included in Cyril Davenport, 


\section{2 | Journal For Manuscript Studies}

Department of the Ellis Library of the University of Missouri at Columbia. ${ }^{31}$ I have found no allusion to or specific link with the Machiavelli manuscript, though this is only a provisional statement. The only possible allusion to the manuscript is in Sloane MS 885, a "Commonplace book of Mr John Bagford," including observations on the art of writing and of printing, catalogues of British writers on various subjects, and so on. On folio $123 \mathrm{v}$, there is, as part of an alphabetical list, a "Machivel" followed by the number 43 - unfortunately, without a date or any other indication.

The collections themselves, even in their mutilated state, give us a sense of Bagford's interests, which have to do with hands and typefaces, layouts, decorations, and in general the visual organization of the texts. The Machiavelli manuscript, with its very modest appearance and lack of rubrication, may have had little interest for this bibliographer; Bagford may have come across it on the occasion of the dispersal of a library. Nor is it possible to reconstruct this manuscript's history prior to its ownership by Bagford: there are very few traces of Machiavelli-related manuscripts in English libraries in the seventeenth century. Apart from the manuscripts containing English translations of Machiavelli's Prince listed above, the existence of at least another is indicated in Edward Bernard's late seventeenth-century Catalogi Librorum Manuscriptorum Angliae et Hiberniae. In the section dedicated to York Cathedral he lists, as note 58, "Machiavil's Prince, English, 8vo;" 32 this

Bagford's Notes on Bookbindings. A Paper Read before the Bibliographical Society, November 16, 1903 (London: Reprinted by Blades, East \& Blades, from the Society's Transactions, 1904).

31 Gatch mentions a catalogue of the Fragmenta manuscripta by Karen Gould and Linda E. Voigts as forthcoming for the University of Missouri Press. These manuscript fragments are "usually (but by no means always) folia, bifolia, or strips of parchment that had been incorporated in bindings" (Gatch, "John Bagford as a Collector and Disseminator," 96). Unfortunately, the catalogue was never published; however, the collection of manuscript fragments has now been digitized (with the descriptions provided by Gould and Voigts in the form of notes) and appears in the Digital Scriptorium database (http://vm136.lib.berkeley.edu/BANC/ digitalscriptorium/). I wish to thank Timothy Perry, special collections librarian of the University of Missouri Libraries, for his help on this point.

32 Edward Bernard, Catalogi Librorum Manuscriptorum Angliae et Hiberniae in Unum Collecti, cum Indice Alphabetico (Oxford: E Theatro Sheldoniano, 1697), vol. 2, part 1, 4. Bernard's catalogue included also the manuscript now known as Oxford, Bodleian Library, MS Ashmole 792 (vol. 1, part 1, 345, described as "The Prince of Nicholas Machiavel; translated into 
extremely concise description cannot of course allow any identification with any of the surviving manuscripts, though it is tempting to think it may coincide with the manuscript now held in Lambeth Palace Library.

The translation is written in a fairly clear secretary hand, though occasionally constraints of space make it cramped; proper nouns, places and main concepts (Comon weales, Monarchies, etc.), and sometimes gnomic sentences are italicized, in larger characters than the rest. Such a practice is similar to what we find in translation C (Oxford, Queen's College MS 251). The spelling is remarkably consistent. Corrections are in the same hand as the main text. The dedicatory letter to Lorenzo de' Medici, which opens The Prince in the Italian version, is not present, as in translation C; neither $\mathrm{C}$ nor the Sion translation includes a table of contents, unlike translations $\mathrm{A}$ and $\mathrm{B}$ (translation D has survived only in draft). Chapters are almost always numbered, with the exception of chapters I and II; titles are always clearly indicated, generally in italics. Page margins are ruled in red, and pages numbered in reddish-brown ink, probably by the same hand. One sheet (corresponding to pp. 151-52) is missing and has been clearly cut away from the rest. This page would have included the opening paragraphs of chapter XVII, one of the most controversial of The Prince, in which Machiavelli discusses whether it is preferable for the prince to be loved or feared. What is missing here is a short narrative concerning Cesare Borgia, who thanks to his cruelty had managed to keep together the Romagna. Therefore, the author notes, a prince should not regret being considered cruel. Of course this lack might be due to entirely accidental circumstances, especially as the rest of the chapter is present, without any omission.

The opening page of the Sion translation (fig. 2) is headed "Nicholas Machiauell. HIS PRINCIPLes." The surprising choice of principles for Principe raises the question of which text the English writer was using, since elsewhere there is no misreading of this key word-though, as I will note

English out of the Italian.” The catalogue entry is a copy of the title used in the manuscript itself. If the same principle is applied in the case of the York lost manuscript, then the entry does not correspond to the first words of the Sion manuscript, which are "Nicholas Machiauell his principles.” The point, however, is a moot one. 
below, this might be not a misreading but a deliberate choice on the part of the translator. I am transcribing here the first chapter of Machiavelli's text (followed by a modern translation) and of the Sion manuscript translation for a first comparison, which allows us to see some of the translator's recurrent choices:

Quot sint genera principatuum et quibus modis acquirantur Tutti gli stati tutti e dominii che hanno avuto et hanno imperio sopra gli uomini, sono stati e sono o republiche o principati. E principati sono o ereditarii, de' quali el sangue del loro signore ne sia suto lungo tempo principe, o sono nuovi. E nuovi, o e' sono nuovi tutti, come fu Milano a Francesco Sforza, o sono come membri aggiunti allo stato ereditario del principe che gli acquista, come è el regno di Napoli a re di Spagna. Sono questi dominii così acquistati o consueti a vivere sotto uno principe o usi ad essere liberi; et acquistonsi o con le armi d'altri o con le proprie, o per fortuna o per virtù. (I.1-4) ${ }^{33}$

The different kinds of principality and how they are acquired All the states, all the dominions that have held sway over men, have been either republics or principalities. Principalities are either hereditary (their rulers having been for a long time from the same family) or they are new. The new ones are either completely new (as was Milan to Francesco Sforza) or they are like limbs joined to the hereditary state of the ruler who annexes them (as is the Kingdom of Naples to the King of Spain). States thus acquired are either used to living under a prince or used to being free; and they are acquired either with the arms of others or with one's own, either through luck or favour or else through ability.

33 The edition used throughout is Niccolò Machiavelli, De principatibus, ed. Giorgio Inglese (Rome: Istituto Storico Italiano per il Medio Evo, 1994). 
How MANY Kindes of Principallities there ARE AND by What MEANES THEY ARE GOTTEN ${ }^{34}$

All Estates and signiories wich haue had and doe beare rule ouer men, haue either byn and are COMON weAles or Monarchies Now Monarchies are helde either by right of inheritaunce (that is to saye of the mighte the ancesters of him who nowe is Lorde of him hath of antiquitie byn possessed) or ells they are newly gotten. / And soe they are eyther entirelye and in their totallitye newe, as the Dutchie of Millayne was to Frauncis Sforza or other wise they are as members adioyned to the hereditarie estate of the prince who hath conquered them as att this day the kingdom of Naples is to the KING OF SPAYNE.

Now thes Signories soe gotten are wont in former tyme either to be subiect to one prince alone, or to lyve in free manner: And they are purchased either by forraigne force, or [their?] ${ }^{35}$ owne power, or by fortune, or ells by vertue. /

The translator strives for fidelity, adhering to Machiavelli's choice of keywords such as fortuna and virtù, given as simple calques, and deviating from the original only to clarify a concept by means of a synonymic couple or an extra adjective. He eschews the Latin translation's tendency "to construct more complex sentences," 36 and in any case appears not to follow any of Telius's choices, working directly from the Italian. ${ }^{37} \mathrm{He}$ is preoccupied for the reader to understand all references to Italian city-states and non-Italian

34 I have transcribed in small caps the italicized words in the manuscript.

35 A symbol appears here that might be read as "their."

36 Caterina Mordeglia, "The First Latin Translation," in The First Translations of Macbiavelli's Prince: From the Sixteenth to the First Half of the Nineteenth Century, ed. Roberto De Pol, 59-82 (Amsterdam: Rodopi, 2010), 70.

37 For instance, the passages omitted in the Telius translation appear in this version. For a first comparison between the original and Telius, see Leandro Perini, "Gli eretici italiani del '500 e Machiavelli," Studi storici 10 (1969): 908-14, and Mordeglia, “The First Latin Translation.” 


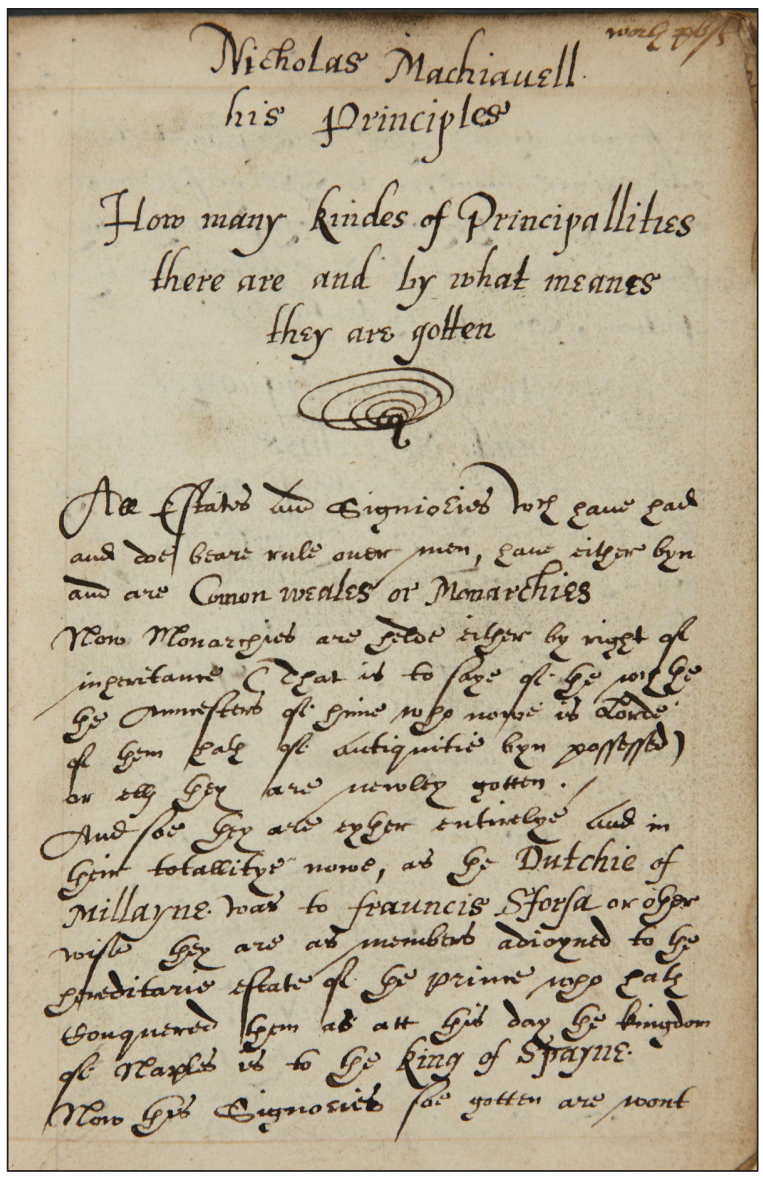

FIGURE 2. London, Lambeth Palace Library, MS Sion

L40.2/E24, p. 1. Reproduced with permission of Lambeth Palace Library.

potentates. It may be useful to compare this translation of chapter I with other early modern English translations:

(A) Whatsoever state of government either hath ben, or nowe is emongst men, the same maybe called either populer where all or many beare the swaye, or princely, where one alone hath the soveraignty. The Pryncely states doe either discende by inheritaunce to them whose Ancestours of longe tyme haue enioyed the diadem, 
or elles they are newly gotten. These laste are eyther such wherevnto before noe tytle coulde be pretended, as Millayne was to Frauncis Sforza, or elles annexed as it were a parte of the inherited state of the Prynce that inioyes the same; as the kingdom of Naples was to the kynge of Spayne. The states of government soe gotten, are either accustomed to live under the obedience of a Prynce, or free withowt controllment, and they are woonn either by foraine force, or our owne, by fortune or vertue. ${ }^{38}$

(B) All the estates and segniories that haue had rule ouer men haue binne either commonwelthes or monarchies. Now monarchies ar possessed either as inheritances (that is to saie dominions whereof ther awncestors, whiche inioye them, haue binne in long possession, or else thai be newe. The new ar either inteerlie and altogether new, as was the dukedome Millaine to Ffrancis Sforza, or else thai as it wear members ioyned to the state of inheritance of the Prince that hathe conquered them, as is the realme of Naples to the King of Spaine. Of the segnioris so gotten, somme have binne accustomed to bee in subiection to a Prince, somme other to liue in libertie. Nowe thai ar gotten either with the armes and ayd of others or with out owne proper forces, by fort or by vertwe. ${ }^{39}$

(C) Cap: $1^{\circ}$.

All formes of Government, are properly comprised, under one of these twooe: kingedoms: or common wealthes.

Kingedomes are ayther hereditarie and of ancient discent: or thaye are newee.

38 Cambridge (MA), Harvard University, Houghton Library, MS Eng. 1014, fol. 3r. For this and other quotations from this translation, see Hardin Craig, Machiavelli's The Prince: An Elizabethan Translation. Edited with an Introduction and Notes from a Manuscript in the Collection of Mr. Jules Furthman (Chapel Hill: University of North Carolina Press, 1944).

39 London, British Library, MS Harley 364.xx, fol. 47r. For this and other quotations from this translation, see Valeria Tagliabue, "Il Principe di Machiavelli in una traduzione inedita del Rinascimento inglese (B.L. MS. Harley 364),” Laurea dissertation, Università Cattolica del Sacro Cuore di Milano, 1993-94. 
The newee are eyther entyer: or adioyned to some other ancient estate of a kinge, as a member therof.

Thes dominions thus gotten: eyther weare accustomed to liue under the governement of a prince: or lived freelye.

Thay are achiued, eyther by the armes of others: or by ones owne power: by vertewe: or bye fortune. ${ }^{40}$

(D) Hou manye sorts of gouernments they be and be quhat moyens they are procured and increased. Chap. 1

Quhat sumeuer government or estate that hes or hes had commandiment ouer men hes bene and ar ather Commoun welths or monarcheis. now Monarchies ather ar hereditaire that is to say or newe. hereditaire I call these quha from all antiquitie and discent ar possessed be him that is present Lord and Soveraine. the newe againe ar ather whollye and altogeather newe and vncouthe as the duikdome of milan to francis forze: Or ars ar as members and limms adioned and coupled to the heratiballe heritable estate off the prince that hes conqueste and obtened theme as this day we do see Naples to the king of Spaine. So that Yet sic governments so encreased and purchessed and obtined, wer accustomed wer wount and accustomed ather afore to be vnder the subiection and obedience of a prence or to liue in libertie. The reule and commandement wheroff was obtened ather be the ayde and armeyes of some other or by his auen pouer forces fortune or vertew. ${ }^{41}$

There is an enormous variety in the approaches of the different translators to this passage. Some translators begin with variant forms of whatsoever, introducing a subordinate clause, thus preparing the reader to a complex sentence; others prefer the more direct all, replicating Machiavelli's tutti and its sudden simplicity. In its predilection for parataxis over hypotaxis, the Sion transla-

40 Oxford, Queen's College, MS 251, fol. 1r. For this and other quotations from this translation, see Petrina, Machiavelli in the British Isles, 201-55.

41 Edinburgh, National Library of Scotland, MS Hawthornden 2064, fol. 144r. For this and other quotations from this translation, see Petrina, Machiavelli in the British Isles, 138-99. 
tion is close to translation $\mathrm{C}$, though it is not as trenchant and epigrammatic, and though it adheres as closely as possible to Machiavelli's Italian. Without lapsing into the verbosity and anadiplosis of translation D, it strives to explain (occasionally in parentheses) Machiavelli's denser passages, maintaining syntactic clarity while trying to make sense of the original's semantic vagueness.

Another comparison can be proposed for a problematic passage in chapter III. Here Machiavelli draws a long list of Italian city-states, which gave their allegiance to the king of France; his sequence of names gives a sense of the increasing urgency (and perhaps lack of decorum) with which the various princes jostled in order to be admitted to the king's favor:

Acquistata adunque el Re la Lombardia, subito si riguadagnò quella reputazione che gli aveva tolta Carlo: Genova cedé; Fiorentini gli diventarono amici; marchese di Mantova, duca di Ferrara, Bentivogli, Madonna di Furlì, signore di Faenza, di Rimini, di Pesero, di Camerino, di Piombino, Lucchesi, Pisani, Sanesi, ognuno se gli fece incontro per essere suo amico. (III.34)

When he had conquered Lombardy, then, the King at once regained the power and prestige that had been lost by Charles. Genoa surrendered, the Florentines became his allies; the Marquis of Mantua, the Duke of Ferrara, Bentivoglio, the Countess of Forli, the rulers of Faenza, Pesaro, Rimini, Camerino, Piombino, and the people of Lucca, Pisa and Siena: all of them moved to ally themselves with him.

This passage is difficult for early modern English translators, given the allusions to tiny city-states that might be unknown to the translator or the prospective reader. ${ }^{42}$ Contemporary translators thus adopted different strategies. In most cases they tried to reproduce Machiavelli's original text with

42 Though some English translators misunderstood Faenza and Forli (and occasionally others), such misunderstandings do not appear in the early Italian, French, or Latin editions (Craig, Machiavelli's The Prince, 129-30). 
a varying degree of success, as can be seen below (with an elegant exception in the case of translation C). When the name is understood, as in the case of Forli, the translator may use the Latin equivalent Forum Iulii; the less known Faenza and Lucca yield hilarious results in the first two translations, while only translation D (written by William Fowler, who had spent a considerable time traveling in Italy) appears acquainted with all these names:

(A) Ffor the kinge himself havinge gotten Lumberdie, he presentlie recovered that estimation and honour which Charles had pulled from him before. Genua yelded, the Florentines became his frendes the States of Mantua and Ferrara, Bentiuoly maddam of Furly, the Lorde of Facuza, of Pezaro, of Rimino, of Camerino, of Piombino, the Lucaenes, the Pisanes, the Senesians, all these enterteigned him and desyred his amitye. (fol. $6 \mathrm{r})^{43}$

(B) The kinge then hauinge passed Lumbardy had recouered in short space the honor that Kinge Charles might have taken from him, Genoa had yeilded it self, the fflorentines became his freinds, the Marquesse of Mantua, the Duke of fferrara, the Bonognians, the Ladie of forum Julii, the Lorde fforonze of Pesaro of Rimni, of Camerin, of Plombin, the Laquies Pisanes Sienoiis euerie one of them came to him to bee at his comaundont.

(C) Upon the winninge ther of: all the smales estates of Italy associated them selues with him. (fol. 5r)

(D) for he having subdewed Lumbardi he with the same recovered this whole reputation that kings Charles before had lossed, and forcing brought Genua to rander ${ }^{\text {maid }}$ the florentins ${ }^{\text {to }}$ become his friends so that the Marqis of mantwa the duk of ferrar the bentiuolles of bullongne the contesse of furlye the lords off faense of pesare off ari-

43 In this case, though following Craig's edition, I have eliminated the emendations he inserted and acknowledged in his note 36 . 
min of camerin of plombin these of Luca of Sienna Siena and of pisa euerye ane and all former off these former suddenlye sought his favour and friendship (fol. 153v)

The Sion translation opts for literal faithfulness, and though it betrays its ignorance of some of the names used by Machiavelli, it maintains the original pace, and strives to make the place-names understandable to the reader:

hauinge then brought Lombardy under his subiection on the suddaine he recovered all the reputation wich King CHarles had lost him before imediatlye thereuppon $\S$ GENEUA was yelded, the Florentines became his friends, likewise the Marques of Mantua, the Duke of Ferrara' the Bentiuoll' of Bullogne' the Countes of Furts the Lord ${ }^{\prime} \mathrm{FA}^{\mathrm{C}}$ UXET of PIZARA of Axuino of Camorino of Piombino, those of Luca of Siena and of Pisa all these came to offer them selves vnto hime to gayne his love and freindshipp. (pp. 18-19)

In general the translation is very clear and literal, occasionally enlarging very slightly on the original, especially as concerns allusions to the contemporary Italian political reality. The translator strives for a more linear syntax than the original, setting clearly each subject before its verb, and not vice versa, as Machiavelli is wont to do, and occasionally solving a complex noun phrase into a longer but more easily understandable subordinate clause. Thus the phrase "trovandosi ingannati della opinione loro" (III.4; "deceived in their own belief" $)^{44}$ is translated as "findinge that their owne opinion had deceived them" (p. 6). The necessity to clarify allusions to contemporary drives him to complete an abbreviated chronological reference and employ hendiadys:

Noi abbiamo in Italia, in exemplis, el duca di Ferrara, il quale non ha retto alli assalti de' Viniziani nell'ottantaquattro, né a quelli di

44 My translation. 
papa Iulio nel dieci, per altre cagioni che per essere antiquato in quello dominio. (II.4)

To cite an Italian example: The Duke of Ferrara resisted the assaults of the Venetians in 1484, as well as those of Pope Julius in 1510, just because his family was very well established in that state.

For example whereof wee haue in Italye the Duke of FERRARA who made noe other resistance to the assaulte and warres wich the Venetians made against hime in the yeare 1484 and POPE Julio in the yeare 1510 then by the meanes of the antiquitie of his howse in that duchie./ (p. 3$)^{45}$

The vocabulary appears limited, and it often attempts to offer straightforward semantic calques for the original words. On the grammatical level, when Machiavelli uses the impersonal form introduced by "si," the translator sometimes uses “a man," sometimes "thou." In general, the writer strives to be as faithful as possible to the original, normally rendering the same Italian word with the same English word/expression, with few exceptions: principati, for instance, becomes alternately monercbies and principallities, possibly highlighting the English translator's difficulty with a typically Italian form of government. Obviously this is a problem encountered by all translators of The Prince: as Sydney Anglo drily notes, one of the Italian writer's notable stylistic traits "is the remarkable limitation of his political vocabulary. . . . Paradoxically, the strong, qualitative words give an impression of diamond-hard, uncompromising thinking, while, in fact, blurring ideas and keeping them perpetually out of focus." ${ }^{\prime 36}$ Translators attempting to offer different terms for fortuna or virtù will simply show the fallacies in Machiavelli's reasoning, while losing his elegant clarity; the anonymous translator of Sion L40.2/E24 achieves a remarkable closeness with a faithful version that interpolates clarifications in parenthetical clauses. It is as if this

45 The two dates are underlined in the original, in the same ink as the main text.

46 Sydney Anglo, Machiavelli: A Dissection (London: Gollancz, 1969), 242-43. 
translation was meant for a reader approaching the original text and needing a sort of commented, explanatory version.

The impression is reinforced when we take into consideration the paratextual material present in the manuscript. Marginalia are reasonably frequent; in over thirty instances the word "Nota" appears (on three occasions, "Nota Bene"). This, together with the occasional underlining of single words throughout, and the regular uniformity of the script, shows that the manuscript was completed without any hurry, and is well organized throughout; the same scribe prepared text and paratext. On other occasions the marginalia simply consist in a reminder that a historical character is being discussed in the text: thus, on page 47, the marginal note repeats "Hiero de: Siracusa” (in Machiavelli's original, Ierone Siracusano), a name already appearing in the text. On page 59 the marginalium "Sg Remirro Dorco" (Remirro de Orco) repeats the name used in the text. There is also the case of "Oliuer of Fermo" (Oliverotto Firmiano) on pages 75 and 80. "Alex :6:" (Pope Alexander VI, Rodrigo Borgia) and "Julius" (Pope Julius II) appear on page 106; "Leo" (Pope Leo X) on page 109; “Charles :8:" (King Charles VIII of France) on page 112. As for classical names, the only instances are "Roma," "Sparta," and "Carthaginians" (p. 114), "Philopomenes" (p. 136) and "Caesar" (p. 148); there is only one marginalium used to recall a biblical name ("Dauid," p. 128). The scribe was either convinced that a reader would easily pick up allusions to classical or biblical names, or else wanted readers to focus on contemporary Italian politics. On very few occasions are marginalia used to indicate not a person but an event, or a concept: on page 16, "feauer Hectica"; on page 27 the marginalium reads "Turke," repeating a word used in the text. We also have references to places: on page 66 the word "Romagna" repeats the word used in the text, while an allusion to the king of France is highlighted by the word "France" (p. 28). Since normally the same name appears also on the same line in the text, clearly highlighted in the writing, what this use of marginalia suggests is a tool for the scanning rather than the intensive reading of the text. Although this habit is not confined to early modern reading, it does become systematic and widespread at the time; as Andrew Hadfield has noted, "such usage may be linked to early modern reading habits, since sixteenth-century readers were often extremely specific in the ways in which they approached texts, using 
them to extract the precise information they needed, concentrating on key passages to further their particular arguments (some aristocratic readers even paid scholars within their households to underline passages from them to scrutinize later). ${ }^{37}$ If this is so, the reader of this version had very specific requirements. In some early printed editions of The Prince (for instance, the 1571 French translation by Jacques Gohory) there are printed marginal notes drawing the reader's attention to the person, place, or topic being discussed in that particular passage; there are also, occasionally, printed manicula. No such marginalia appear in the early editions in Italian.

On page 55 (chapter VII), while the city of Faenza becomes "Facuza," Bologna becomes "Bolognia la grassa," a phrase attested in John Florio's Giardino di Ricreatione (1591), a list of Italian proverbs appended to his Second Fruites, in the form "Bologna la grassa, Padoua la passa"; 48 "King Louis" is added in the margin, while Machiavelli simply writes "il re," by these means clearing a possible confusion between "the king" and "the duke" (fig. 3). Thus the scribe strives for maximum readability, even for readers unacquainted with the minutiae of Italian politics - an impression borne out by the translation.

Particularly interesting is the Nota on page 17 . Here, halfway through chapter III, Machiavelli becomes sententious and stops his historical narrative:

Né piacque mai loro quello che è tutto dì in bocca de' savi de' nostri tempi, di godere il benefizio del tempo, ma sì bene quello della virtù e prudenza loro: perché il tempo si caccia innanzi ogni cosa, e può condurre seco bene come male e male come bene. (III.30)

47 Andrew Hadfield, Shakespeare and Renaissance Politics (London: Thomson, 2004), 18. 48 John Florio, Giardino di Ricreatione nel quale crescono fronde, fiori e frutti, vaghe, leggiadri, e soaui, sotto nome di sei mila Prouerbij . . . (London: Thomas Woodcock, 1591), 16. The proverb may be translated as "Bologna the fertile, Padua surpasses her." The phrase is also current in France (where it sometimes becomes the elegant "Bologne-la-grace"), already from the first half of the sixteenth century. I would like to thank Giovanni Iamartino and Franca Zanelli for their help on this point. 


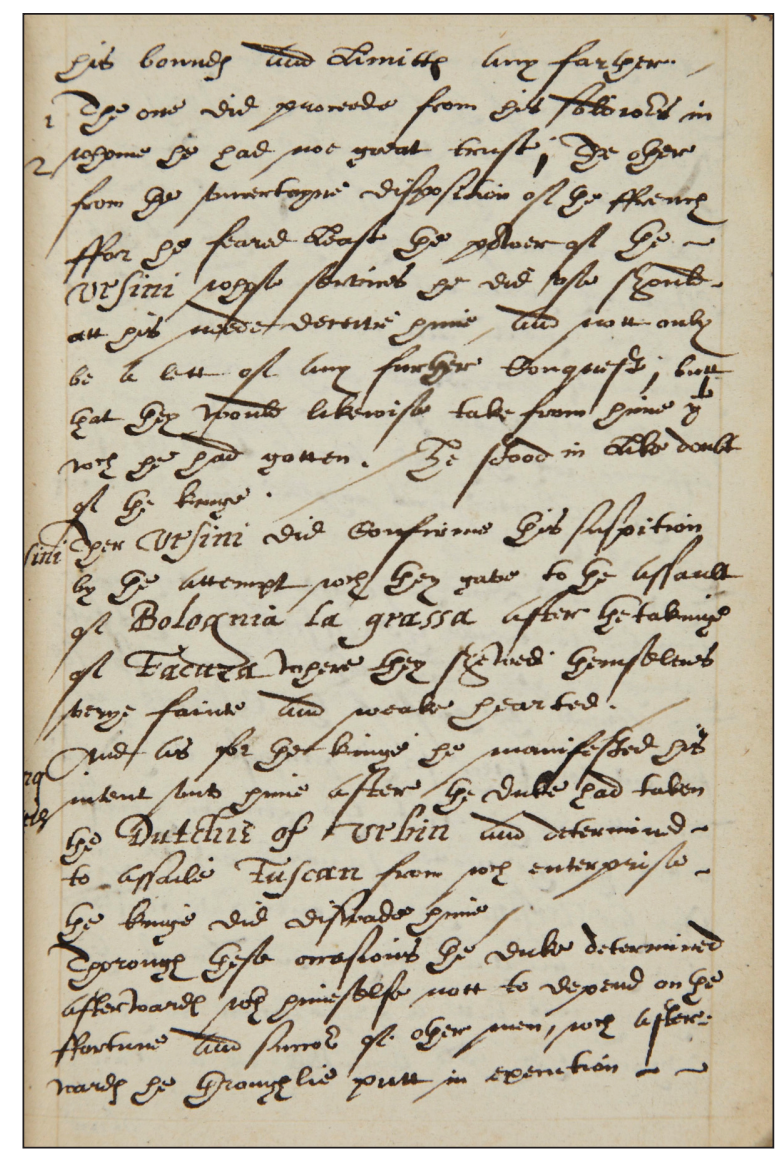

FIGURE 3. Lambeth Palace Library, MS Sion L40.2/E24, p. 55. Reproduced with permission of Lambeth Palace Library.

Moreover, the Romans never accepted a maxim heard every day on the lips of our sages, to seek a benefit from temporizing. They preferred to enjoy the benefits that derived from their own strength and prudence; because time brings all things with it, and can produce benefits as well as evils, evils as well as benefits.

The translator makes use of a clearer, larger writing in order to highlight the gnomic part, thus translating the passage: 
THAT WEE OUGHT TO ENJOY THE COMMODITIE OF THE TYME AS IT HAPENETH did nott please them: butt contrarily they followed a sentence formyinge from their owne wisdom and virtue that TYME CARRIETH ALL THINGS WITH YT \& MAY AS WELL BRING WITH YT GOOD AS EUELL \& EUELL AS GOOD.

Next to "THAT weE OUGHT" the scribe has written "Nota" on the margin. Evidently the scribe is highlighting sententiae for the use of specific readers. Finally, there are two longer marginal notes, one of which helps the translator overcome the obscurity of a passage and is offered as an intermediary explanation to the reader. In chapter VII, Machiavelli attempts a final evaluation of Cesare Borgia, identifying his one real mistake:

Solamente si può accusarlo nella creazione di Iulio pontefice, nella quale il Duca ebbe mala electione. Perché, come è detto, non potendo fare uno papa a suo modo, poteva tenere che uno non fussi papa; e non doveva mai consentire al papato di quelli cardinali che lui avesse offesi o che, divenuti papi, avessino ad aver paura di lui: perché gli uomini offendono o per paura o per odio. (VII.44-45)

He can be criticised only with regard to the election of Pope Julius, in which he made a bad choice; as has been said, even if he could not ensure that the man he favoured was made pope, he could have prevented certain other choices. And he should never have permitted any cardinals he had injured to be chosen, or any who, once he became pope, would have reason to be afraid of him. For men harm others because they fear them or because they hate them.

For a non-Italian reader, this passage may be extremely confusing. Pope Julius II is cursorily referred to as "Iulio pontefice," and the last explicit mention of Cesare Borgia is by now forgotten-over the previous pages Machiavelli refers to him only as the Duca. The English translator is forced to expand: 
A man may onlie blame hime for one thinge that he suffered the election of Julius the second ${ }^{49}$ wich was greatlye preiuditiall unto hime: ffor (as I haue recited) seeing he could nott create such a pope as he would it was possible for him to haue held such a hand there in as none of all those CARDinalle whome he had before made his ennemies would haue attained therevnto, or that hauinge attained to that dignite would nott haue stood in feare of him ffor soe much as men comonlie the lesse forse themselues to hurt thoroughe feare then envie / (p. 69)

Evidently uneasy with a still unclear translation, he adds a long marginal note (fig. 4),

the only fault in Ceser Borgia was $\mathrm{y}^{\mathrm{t}}$ he sufered Julius $\mathrm{y}^{\mathrm{e}}$.2. to be elected pope after $y^{\mathrm{e}}$ death of .P. Alex. $\mathrm{y}^{\mathrm{e}} \cdot 6^{\circ}$

Although we lose the consequentiality of the original, the marginalium restores the historical reference. The presence of this note, together with other features of this manuscript, suggests that the work was meant as historical, rather than political.

The other long marginal note underlines the value of The Prince as an epigrammatic text; as has been noted above, English readers delved into Machiavelli's work to draw a collection of aphorisms. The note is appended to a passage in chapter XII, dedicated to mercenary armies. The Italian writer maintains the uselessness and potential danger inherent in the employment of paid soldiers:

La qual cosa doverrei durare poca fatica a persuadere, perché ora la ruina di Italia non è causata da altro che per essersi per spazio di molti anni riposata tutta in sulle armi mercennarie. Le quali feciono già per alcuno qualche progresso, e parevano gagliarde infra loro; (XII.8-9)

49 Note that the original only has "Iulio pontefice." 


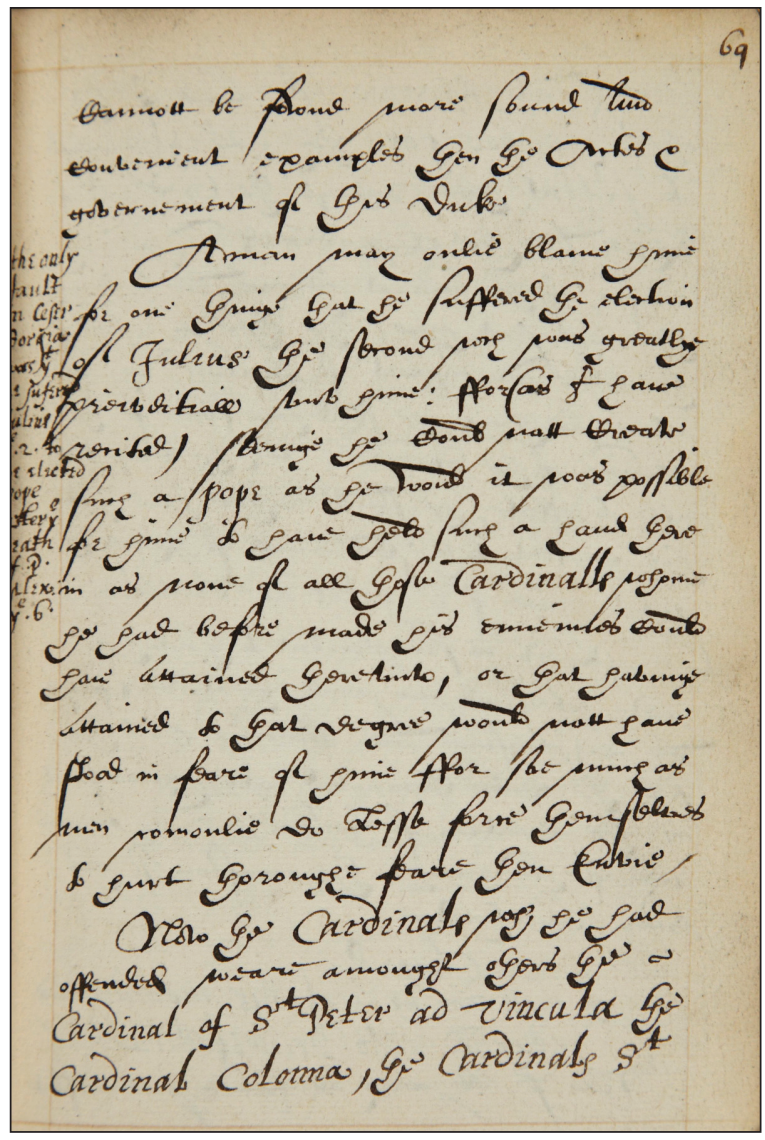

FIGURE 4. Lambeth Palace Library, MS Sion L40.2/E24, p. 69. Reproduced with permission of Lambeth Palace Library.

I should not need to spend very much time in arguing this case, since the present ruin of Italy has been caused by nothing else than the reliance over so many years on mercenary armies. Some of these mercenary armies were not ineffective, and they appeared powerful when fighting other mercenary armies.

The information offered has the value of an obiter dictum, but at the same time is closely connected to the discussion on the state of affairs in Italy. The translator first chooses a literal version, which dilutes the meaning: 
Wich may safelye perswade us that the distruction of ITALY hath bene occasioned by noe other meanes, then because they did for many yeares putt confidence in mercenarie soldiers/ who itt may be haue in former tyme made good proof of them/ serving under some man had from theme stolen the reputation of valiant men: (p. 112)

Then the marginal note offers a forceful summary:

Trust in Mercinary soldiers $y^{\mathrm{e}}$ only cause of $\mathrm{y}^{\mathrm{e}}$ Destruction of Italy

This choice ensures memorability to the passage and helps the reader to forget the weaknesses of the main text.

One last instance shows the usefulness of marginalia for this particular translator, and his desire to make the text as clear as possible to the reader. Toward the end of chapter III, Machiavelli offers a short list of the mistakes made by King Louis of France in his attempt to subjugate part of the Italian peninsula:

Aveva dunque fatto Luigi questi cinque errori: spenti e minori potenti; accresciuto in Italia potenza a uno potente; messo in quella uno forestiere potentissimo; non venuto ad abitarvi; non vi messo colonie. (III.42)

Louis, then, made these five blunders: he extinguished the minor powers; he increased the power of a ruler who was already powerful in Italy; he brought into Italy a very strong foreign power; he did not institute direct rule, and he did not set up colonies.

The list, drastically condensed in the original, is difficult to follow (even the modern translator opts for a construction made of five parallel and finite clauses, while Machiavelli achieves a rapid conclusion by non-finite clauses). The French translator Gaspard d'Auvergne attains the same effect by making use of analogous non-finite clauses: 
Le Roy Loys avoit doncq faict, et commis ces cinq grandes fautes. C'est à sçavoir adnichillé les petitz seigneurs, augmenté en Italie la puissance a un puissant, receu et appellé en icelle un trespuissant estranger, ny estant point venu pour y demeurer longuement, et n'y ayant point envoyé de Colonies pour habiter.

The English language, however, makes this choice particularly difficult. Translation A opts for finite clauses:

And thus did Lewes fall into five errours; the weaker sorte he cutt of, the power of the mightie he enlarged in Italie, hee brought in thither a most puissante mightie Prynce, he planted noe Colonies there neither wente he thither to inhabite (fol. 6v)

Translation C follows the same strategy, but writes not only what the king did, but also what he should have done:

Lodouike then committed thes fiue errors. hee wasted the lesser states: whome he showld haue preserued. he increased in Ittaly the power of one allredy very potent: which hee showld haue abased. hee broght in a potent forriner: whome hee showld haue kept owt. he Inhabited not the Contrye vanquished: which hee oght to haue doun. Nayther planted hee thear in, any Colonye. (fol. 7r)

This version shows the conflicting requirements of faithfulness and clarity. Translation D adopts a different method, which does not yield felicitous results:

The king then hes committed in this his Interpryse fyfe great faultes to witt ane In debaising and bringing to nothing the litill potentates the secound in augmentinge and inlarging in italye the pouar of a puissant pape. the thrid to have brought and called in to be compartner with him a overmightie stranger. the 4 not resolving to mak residence langar amangst theme and the 5 in not sending 
colones and in not transporting some off his auen natiue pepill to Inhabit the new conquest. (fol. 154v)

Although this version is confused and almost illegible, it does point out that the detail that risks being lost in a faithful version is the fact that Machiavelli is providing a list of errors. The Sion translator explores this possibility more in full, opting for a clearer layout: the five numbers indicating the king's five mistakes are set outside the main text, while the use of punctuation helps the separation of the items in the list (fig. 5).

KING LEwIs then made and committed these ffyue faultes to witt. /

1 To haue made noe accompt of the litle Lords. /

2 To haue in Italye increassed the power of a mightye one. /

3 To haue received and called into Italye a most puissant stranger. /

4 He hime selfe beinge nott come thither to make any longe abode there

5 And hauinge nott sent colonyes to inhabite them (p. 22)

Thus the non-finite clauses can be maintained and the original construction preserved in its original strength, while clarity is if anything intensified. The transformation of Machiavelli's lists into numbered sequences appears also elsewhere.

Such a layout lends itself particularly well to a pedagogical approach, ${ }^{50}$ which suggests a new direction in the study of the English reception of Machiavelli, in keeping with recent studies on early modern modes of reading. The Macheuill beloved of the English stage, the semi-comic devil evoked by Marlowe and Shakespeare, is only part of the picture. The Prince was also read seriously and attentively: in some cases it seems that the translators chose this short, clear, and lexically poor text as a sort of linguistic exercise, as seems clear by a close scrutiny of William Fowler's

50 I wish to thank David Rundle for this suggestion; Rundle notes that the layout of the Lambeth MS reflects the reading habits and/or school habits of early modern readers. 


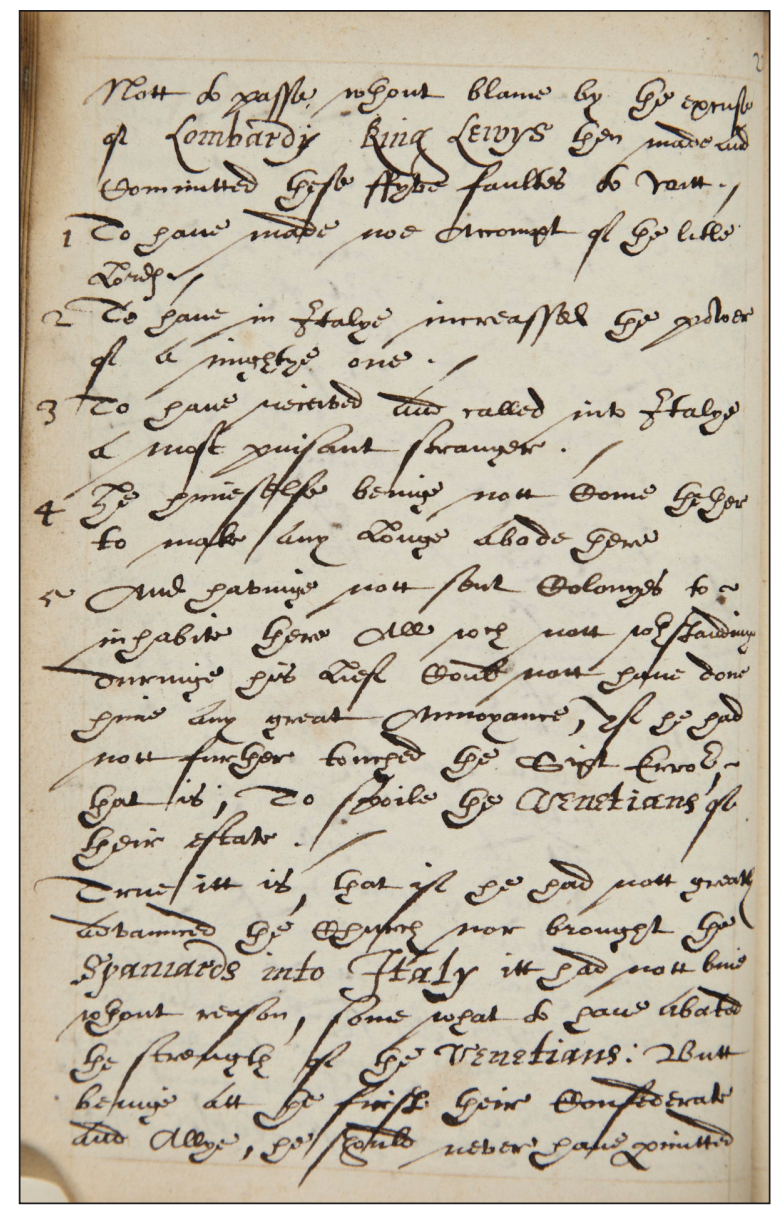

FIGURE 5. Lambeth Palace Library, MS Sion L40.2/E24, p. 22. Reproduced with permission of Lambeth Palace Library.

translation. ${ }^{51}$ The translation extant in Sion L40.2/E24 highlights early modern interest in The Prince as a historiographical commentary and a

51 For an analysis of Fowler's translation as a linguistic exercise, see Petrina, Machiavelli in the British Isles, 124-29. On the practice of translation as an aid to language learning, see Jason Lawrence, "Who the devil taught thee so much Italian?": Italian Language Learning and Literary Imitation in Early Modern England (Manchester: Manchester University Press, 2005), 45. 
book of political precepts, showing analogies with what we may notice in Oxford, Queen's College Library, MS 251, in which topics that may be of interest to the reader are listed at the end of the translation. ${ }^{52}$ At the same time, the linguistic choices of the translator of the Sion manuscript, together with the paratext and layout, indicate a clear ideological attitude: the tendency to transform this often elliptical, dense text in a clear guide, a manual for good government to which a reader might recur for one or the other sententia or exemplum. Machiavelli is no longer a frightening Satanic writer but, quite simply, a scientific author; as such, he needs careful explanation where necessary, and pointers to the reader, who is guided thanks to the carefully disseminated marginalia to an appreciation of the gnomic value of the argumentation. Such a presentation posits The Prince as a text with a twofold value: on the one hand, it is a repository of sayings, as highlighted by its use in commonplace books and collections of sententiae (as described in the opening section of the present article); on the other, it asserts itself as an established philosophical treatise, to be studied in its entirety. The former approach may bring us back to the title appearing in this manuscript, in which, as noted above, principles is chosen in preference to the more obvious principalities, as if the translator were indicating from the outset the use for which this book was intended in this particular environment. ${ }^{53}$ The later approach will become extremely important in the mid- and late seventeenth century, with the reaction to Machiavelli on the part of English philosophers and political thinkers, from Anthony Ascham to James Harrington to Thomas Hobbes. The manuscript recently rediscovered in Lambeth Palace Library not only offers further testimony of the popularity of Machiavelli's Prince in the first century after its composition; it also provides a fascinating insight into the modalities of reading in early modern England.

52 An analysis is provided in Alessandra Petrina, "A Treatise of several forms of Government": A Sixteenth-Century English Translation of The Prince," in Machiavelli's Prince: Traditions, Text and Translations, ed. Nicola Gardini and Martin McLaughlin, 177-90 (Rome: Viella, 2017).

53 I wish to thank the anonymous reader of the journal for this invaluable suggestion. 


\section{LIST OF MANUSCRIPTS CITED}

Baltimore, Walters Art Museum

W.527: 374 n. 33

W.530.A: 374 n. 33

W.531: 374 n. 33

W.838: 358, 360, 362, 362 fig. 5, 364

table 1, 365-77, 380-2

W.839: 358, 360, 361 fig. 4, 362, 365-77, 370 n. $29,380-2$

W.840: 358, 360, 360 fig. 3, 365-77, 370

n. $29,380-2$

\section{Boru Śəllase Monastery}

Gospels of Boru Śllase: 367, 367 n. 17, 369-72, 373 fig. 7, 374-82, 376 fig. 8, 378 fig. 9

Cambridge, MA, Harvard University, Houghton Library MS Eng. 1014: 306, 316-17, 317 n. 38, 320, 330

MS Richardson 28: 441 n. 12, 442 n. 14

Chandigarh, Punjab University, AC Joshi

Library

MS 1428: 292 n. 39

MS M-105: 292 n. 39

Cleveland, Cleveland Museum of Art 1942.1511: 374 n. 33

Däbrä Hayq Hsțifanos Monastery

Gospels of Iyäsus Mo'a: 377-78, 377 n. 40, 379 fig. 10, 381

Däbrä Tä’amina Monastery

Gospels of Däbrä Täamina: 367, 367 n. 18, 369-72, 372 fig. 6, 374-75, 381-82
Dublin, Trinity College Library

MS 58: 366 n. 10

Edinburgh, National Library of Scotland MS Hawthornden 2064: 306, 318, $318 \mathrm{n}$. $41,320-21,330-31$

Florence, Biblioteca Medicea Laurenziana Plut. 1.56: 374 n. 33, 422

The Hague, National Library of the

Netherlands

MMW 10 A 19: 412, 412 n. 57

Jaipur, Maharaja Sawai Singh II Museum MS 2440.28: 288, 288 n. 33

Jaipur, Rajasthan Oriental Research Institute MS 2165: 296

Jodhpur, Rajasthan Oriental Research

Institute

MS 24778: 294 n. 42

MS 26094: 286-87

MS 26334: 277 fig. 3

MS 26579: 296; 297 fig. 6

MS 27518: 284 fig. 4

Leiden, Rijksuniversiteitbibliothek

BPL 108: 435

BPL 111: 435

Scaliger 38: 435

London, British Library

MS 2 B I: 398, 399 fig. 10, 407, 410

MS Add. 5111: 374 n. 33

MS Add. 62925: 403-4, 405 fig. 13

MS Cotton Nero A.x: 383-90, 383 n. 1, 384 n. 3, 388 fig. 1, 389 fig. 2, 390 fig. 3, 
391 fig. 4, 391 fig. 5, 392 fig. 6, 392-407, 394 fig. 7, 395 fig. 8, 401 fig. 11, $406 \mathrm{f}$ ig. 14,408 n. 48, 408 n. 49, 409-20, 411 fig. 15

MS Egerton 1070: 401 n. 32

MS Harley 364: 306, 317, 317 n. 39, 320

MS Harley 966: 305

MS Harley 967: 302, 306

MS Harley 2292: 306

MS Harley 5903: 311 n. 30

MS Harley 5906b: 311 n. 30

MS Harley 5908: 311 n. 30

MS Harley 5909: 311 n. 30

MS Harley 5910: 311 n. 30

MS Harley 5914: 311 n. 30

MS Harley 5915: 311 n. 30

MS Harley 5916: 311 n. 30

MS Harley 5917: 311 n. 30

MS Harley 5918: 311 n. 30

MS Harley 5919: 311 n. 30

MS Harley 5920: 311 n. 30

MS Harley 5921: 311 n. 30

MS Harley 5922: 311 n. 30

MS Harley 5923: 311 n. 30

MS Harley 5924: 311 n. 30

MS Harley 5925: 311 n. 30

MS Harley 5926: 311 n. 30

MS Harley 5927: 311 n. 30

MS Harley 5928: 311 n. 30

MS Harley 5929: 311 n. 30

MS Harley 5930: 311 n. 30

MS Harley 5931: 311 n. 30

MS Harley 5932: 311 n. 30

MS Harley 5933: 311 n. 30

MS Harley 5934: 311 n. 30

MS Harley 5935: 311 n. 30

MS Harley 5936: 311 n. 30

MS Harley 5937: 311 n. 30

MS Harley 5938: 311 n. 30

MS Harley 5939: 311 n. 30

MS Harley 5940: 311 n. 30

MS Harley 5941: 311 n. 30

MS Harley 5942: 311 n. 30
MS Harley 5943: 311 n. 30

MS Harley 5944: 311 n. 30

MS Harley 5945: 311 n. 30

MS Harley 5946: 311 n. 30

MS Harley 5947: 311 n. 30

MS Harley 5948: 311 n. 30

MS Harley 5949: 311 n. 30

MS Harley 5950: 311 n. 30

MS Harley 5951: 311 n. 30

MS Harley 5952: 311 n. 30

MS Harley 5953: 311 n. 30

MS Harley 5954: 311 n. 30

MS Harley 5956: 311 n. 30

MS Harley 5957: 311 n. 30

MS Harley 5958: 311 n. 30

MS Harley 5959: 311 n. 30

MS Harley 5960: 311 n. 30

MS Harley 5961: 311 n. 30

MS Harley 5962: 311 n. 30

MS Harley 5963: 311 n. 30

MS Harley 5964: 311 n. 30

MS Harley 5965: 311 n. 30

MS Harley 5966: 311 n. 30

MS Harley 5967: 311 n. 30

MS Harley 5968: 311 n. 30

MS Harley 5969: 311 n. 30

MS Harley 5970: 311 n. 30

MS Harley 5971: 311 n. 30

MS Harley 5972: 311 n. 30

MS Harley 5973: 311 n. 30

MS Harley 5974: 311 n. 30

MS Harley 5975: 311 n. 30

MS Harley 5976: 311 n. 30

MS Harley 5977: 311 n. 30

MS Harley 5978: 311 n. 30

MS Harley 5986: 311 n. 30

MS Harley 5987: 311 n. 30

MS Harley 5988: 311 n. 30

MS Harley 5989: 311 n. 30

MS Harley 5990: 311 n. 30

MS Harley 5991: 311 n. 30

MS Harley 5992: 311 n. 30

MS Harley 5993: 311 n. 30 
MS Harley 5994: 311 n. 30

MS Harley 5995: 311 n. 30

MS Harley 5996: 311 n. 30

MS Harley 5997: 311 n. 30

MS Harley 5998: 311 n. 30

MS Harley 6795: 306

MS Royal 6 E VI: 396, 396 n. 21

MS Royal 6 E VII: 396, 396 n. 21

MS Royal 16 G VI: 403, 403 n. 40, 404

fig. 12

MS Royal 19 B XV: 393 n. 19

MS Sloane 885: 311 n. 30, 312

MS Sloane 1044: 311 n. 30

MS Sloane 1086: 311 n. 30

MS Sloane 1983: 311 n. 30

London, Lambeth Palace Library

MS Arc.L.40.2/E.23: 307

MS Arc.L.40.2/E.25: 307

MS Arc.L.40.2/E.64: 308 n. 22

MS Sion L40.2/E24: 307-8, 309 fig. 1, 312-15, 316 fig. 2, 318-19, 321-29, 325

fig. 3, 328 fig. 4, 331-33, 331 n. 50, 332 fig. 5

London, University College London

Library

MS Ogden 7: 305 n. 13

Los Angeles, J. Paul Getty Museum

MS 33: 413-14, 413 fig. 16

MS 89: 370-71, 370 n. 31

Manchester, John Rylands Library

Hindustani MS 1: 275 fig. 2

Rylands French 142: 406-7, 407 n. 43

Maynooth, Russell Library

RB36: 431-32, 432 fig. 1, 433 fig. 2, 436, 438

Mehakelegnaw, Abba Garima Monastery

Gärima I: 363, 363 n. 4, 363 n. 5, 366

n. $10,367-68$

Gärima II: 363 n. 4, 363 n. 5, 366, 366

n. 10,367
Gärima III: 363, 363 n. 4, 363 n. 5, 366, 366 n. 10, 367-68

Naples, Università degli Studi di Napoli

L'Orientale

MS ARA 30: 340 n. 14, 342 n. 21, 343 n.

24, 344 n. 28,347 n. 37,356

MS ARA 50: 340 n. 14, 340 n. 15, 342 n.

21, 344-45, 344 n. 27, 345 n. 29, 345 n.

30, 345 n. 31,347 n. 37,356

MS ARA 51: 356

MS ARA 71: 340 n. 14, 343 n. 24, 347 n.

37, 356

MS ARA 93: 340 n. 15, 343 n. 24, 356

MS ARA 259: 345 n. 30, 345 n. 31, 347

n. 37,356

MS ARA [no shelfmark] "Kitāb al-jawāhir al-muntaqāt”: 345 n. 30, 345 n. 31, 347 n.

37, 356

MS ARA [no shelfmark] "Fiqh Ibāḍite": 347 n. 37,356

New York, Metropolitan Museum of Art 57.185.3: 425-26, 427 fig. 2

New York, Morgan Library and Museum MS M.639: 374 n. 33

MS M.828: 363 n. 4, 367, 367 n. 15, 369

n. 28,378 n. 43,381 n. 53

MS M.1078: 396, 397 fig. 9, 409 n. 52

MS M.1112: 425-26, 427 fig. 2

Newark, NJ, Newark Museum

Coll. 96.46.1: 357-58, 358 fig. 1, 365-77, 375 n. 35, 380-82, 380 n. 46-51

Coll. 96.46.2: 357-58, 359 fig. 2, 360, 362, 364 table 1, 365-77, 380-82

Oxford, Bodleian Library

MS Ashmole 792: 306, 312 n. 32

MS. Eng. poet. a. 1: 398, 398 n. 28

MS Junius 11: 396, 396 n. 20

Oxford, Queen's College Library

MS 251: 306, 313, 317-18, 318 n. 40, $320,330,333$ 


\section{Journal For Manuscript Studies}

Paris, Bibliothèque Nationale

MS Éthiopien 32: 365 n. 7, 367-68, 368

n. 18

MS. lat. 964: 435, 435 n. 6

MS. lat. 4892: 435

MS. lat. 5019: 435

MS. lat. 9435: 435

Philadelphia, University of Pennsylvania

MS Codex 85: 442-69, 442 n. 15, 443

n. 16,443 n. 17,443 n. 20,444 n. 21,444

n. 22

MS Codex 736: 441-42, 441 n. 12, 442

n. 14

MS Coll. 390, Item 42: 483

MS Coll. 390, Item 178: 480

MS Coll. 390, Item 292: 484 n. 28

MS Coll. 390, Item 497: 482 n. 25

MS Coll. 390, Item 533: 483, 483 fig. 4

MS Coll. 390, Item 890: 474 n. 10

MS Coll. 390, Item 893: 474 n. 10

MS Coll. 390, Item 896: 474 n. 10

MS Coll. 390, Item 1136: 479 n. 18

MS Coll. 390, Item 1334: 479 n. 19

MS Coll. 390, Item 1567: 482

MS Coll. 390, Item 1783: 485

MS Coll. 390, Item 2053: 484 n. 28

MS Coll. 390, Item 2172: 480

MS Coll. 390, Item 2615: 480, 481 fig. 3

MS Coll. 390, Item 2660: 480

MS Coll. 390, Item 2670: 475 n. 13

MS Coll. 390, Item 2671: 475 n. 13

MS Coll. 390, Item 2672: 475 n. 13

MS Coll. 390, Item 2673: 475 n. 13

MS Coll. 390, Item 2674: 475 n. 13

MS Coll. 390, Item 2675: 475 n. 13

MS Coll. 390, Item 3020: 474

MS Coll. 390, Item 3045: 483

MS Indic 2: 476 n. 15
MS Indic 6: 476 n. 15

MS Indic 10: 274 fig. 1

MS Indic 26: 475 n. 13

MS Indic 28: 275 n. 15

Rossano, Rossano Cathedral, Diocesan

Museum

GA 042: 374 n. 33,422

Šemazānā, Akkala Guzāy, Däbrä Libanos

Monastery

Gospel of Däbrä Libanos: 365 n. 6

Təgray, Church of Qärsäbär Mika'el

Gospels of Qärsäbär Mika'el: 371 n. 32

Vatican City, Biblioteca Apostolica Vaticana

Pal. Gr. 220: 374 n. 33

Vat. Gr. 364: 374 n. 33

Venice, San Lazzaro, Mekhitarist Library

MS 1400/108: 374 n. 33

Vienna, Österreichische Nationalbibliothek Cod. Suppl. Gr. 52: 374 n. 33

Washington, D.C., U.S. Library of

Congress

MS 1-85-154.77: 276 n. 16

Yerevan, Matenadaran

MS 238: 422 n.4

MS 974: 423, 424 fig. 1, 425

MS 2877: 422 n. 4

MS 2930: 422 n.4

MS 3784: 423 n.6

MS 4813: 423 n.6, 426, 428 fig. 3, 429

MS 4818: 422 n. 4

MS 7456: 422 n. 4

MS 7736: 422 n. 4

MS 9423: 422 n.4

MS 10780: 422 n.4 